\title{
Development of a simplified and efficient method for genetic transformation of Gymnoascus reesii
}

\author{
Jian-Hua Liu ${ }^{1}$, Wei Zhang ${ }^{1}$, Xing-Hong Li ${ }^{1}$, Wei-Cheng Liu ${ }^{1}$, Ji-Ye Yan ${ }^{1 \star}$, Ting Liu ${ }^{1 \star}$ and \\ Yu-Xi Duan ${ }^{2 \star}$ \\ ${ }^{1}$ Institute of Plant and Environment Protection, Beijing Academy of Agriculture and Forestry Sciences, \\ Beijing, 100097, China. \\ ${ }^{2}$ Nematology Laboratory, Plant Protection College, Shenyang Agricultural University, Shenyang, 110866, China.
}

Accepted 27 November, 2012

\begin{abstract}
The identification of complex genetic determinants that control the ability of a fungus to produce bioactive compounds enhances molecular breeding strategies. Through a series of optimizations, we developed a system for the genetic transformation of Gymnoascus reesii that can produce nematicidal activity against the root-knot nematode Meloidogyne incoginta. The optimal conditions for protoplast preparation and generation are as follows: mycelia growth time in CM medium of $\mathbf{4 2} \mathrm{h}$, Driselase as the cell wall-degrading enzyme, a ratio of $1.5 \mathrm{~mL}$ enzyme solution $(20 \mathrm{mg} / \mathrm{mL}$ Driselase) per gram mycelia, a treatment time of $4 \mathrm{~h}$ at $28^{\circ} \mathrm{C}$, and $0.7 \mathrm{M} \mathrm{NaCl}$ buffer. With the above conditions, the yield of $\mathrm{G}$. reesii protoplasts reached $1.84 \times 10^{7}$ protoplasts per $\mathrm{mL}$ with a regeneration rate of up to $21.17 \%$ on solid regeneration medium (SR medium). The PKNTG vector with green fluorescent protein (GFP) was transformed into the protoplasts by polyethylene glycol (PEG), and 20 positive transformants were obtained. The results provide a basic technique for molecular breeding of $G$. reesii strains that has improved nematicidal activity.
\end{abstract}

Key words: Gymnoascus reesii, nematicidal activity, genetic transformation.

\section{INTRODUCTION}

Gymnoascus reesii is a soil ascomycete and also a potential material for controlling fungal or nematode diseases in plants. Benjamin et al. (2005) reported that $G$. reesii culture filtrates displayed significant activity against the nematode Haemonchus contortus and significantly inhibited the growth of the bacterium Bacillus subtilis, the plant fungal pathogen Septoria nodorum and a tumor cell line (murine NS-1) (Benjamin et al., 2005, 2006). Liu et al. (2004) reported that they screened a $G$. reesii isolate named Za-130 that exhibited high nematicidal activity against Meloidogyne hapla; they also identified the nematicidal metabolite to be (3E, 5E)-2, 5-dihydroxy-2,7dihydrooxepine - 3-carboxylic anhydride by bioassay-

\footnotetext{
* Corresponding authors. E-mail: jiyeyan@gmail.com, Iting11@163.com, duanyx6407@163.com. Tel.: 86-1051503336. Fax: 86-10-51503899.
}

guided fractionation (Liu et al., 2011).

Developing a well-defined and efficient system for the introduction of DNA into $G$. reesii will facilitate the cloning of $G$. reesii genes that control the production of bioactive compounds. Transformation systems for a number of model ascomycete species have been reported. These systems allow the transformation of Saccharomyces cerevisiae (Hinnen et al., 1978; Schiestl and Petes, 1991), Neurospora crassa (Case et al., 1979), Aspergillus nidulans (Yelton et al., 1984), Magnaporthe oryzae (Parsons et al., 1987) and others. With the whole genome sequencing of the above model fungi and efficient genetic transformation systems, gene knock-out and gene complementary systems have also been established in model ascomycete species (Colot et al., 2006; Hamer et al., 2001). For biocontrol materials, genetic transformation studies have been performed mainly in Trichoderma harziznum, T. reesei and $T$. virde (Penttila et al., 1987; Manczinger et al., 1997; Wang et 
al., 2009). Biocontrol-related genes have also been identified in T. harzianum, Chaetomium cuperium and $C$. globosum by expressed sequence tags (ESTs) (Yang et al., 2007). Good methods for genetic transformation are required for molecular breeding of fungi that produce bioactive compounds more efficiently.

Functional analyses of some biocontrol materials have been carried out in the last several years, and many functional genes were cloned, especially in Trichoderma (Montero-Barrientos et al., 2011; Pozo, 2004). However, the genetic transformation of $G$. reesii has not been reported, and no functional studies have been carried out in this species. Thus, the objective of this study was to create a simple and efficient method for the genetic transformation of $G$. reesii for future genetic engineering of strains that produce bioactive compounds.

\section{MATERIALS AND METHODS}

\section{Chemicals}

Driselase, casein enzymatic hydrolysate, casein acids hydrolysate, and $\mathrm{CaCl}_{2}$ were products of Sigma. Sorbitol and Tris base were Amresco products, and yeast extract and tryptone were from OXOID Company (UK). The agar was bought from Takara Company (Dalian, China), and glucose, sucrose and other common reagents were purchased from Beijing Chemical Reagent Company (Beijing, China).

\section{Strains and plasmids}

G. reesii Za-130 (CGMCC No.2632) used in the present study was isolated by Liu et al. (2004). The isolate was maintained and cultured on potato dextrose agar (PDA) medium in the Biological Control Laboratory, Institute of Plant and Environment Protection, Beijing Academy of Agriculture and Forestry Sciences. The plasmid pKNTG containing neomycin phosphotransferase and GFP under the control of the RP27 promoter was provided by Dr. You-Liang Peng (State Key laboratory for Agrobiotechnology, China Agricultural University).

\section{Medium}

The normal medium PDA was made as follows: $200 \mathrm{~g}$ of potato was boiled for 20-30 $\mathrm{min}$ and then filtered with 4 layer gauze; $2 \%$ glucose and $1.5-2 \%$ agar were added, and $\mathrm{ddH}_{2} \mathrm{O}$ was added to $1000 \mathrm{~mL}$. Mycelium culture was the complete medium (CM, 0.6\% yeast extract, $0.3 \%$ casein enzymatic hydrolysate, $0.3 \%$ casein acids hydrolysate, and $1 \%$ sucrose). The regeneration medium was liquid regeneration medium (LR: $0.1 \%$ yeast extract, $0.1 \%$ casein enzymatic hydrolysate, $1 \mathrm{M}$ sucrose) and solid regeneration medium (SR: LR with $0.7 \%$ agar). The transformation reagents were STC solution (1.2 M sorbitol, $10 \mathrm{mM}$ Tris-Cl, $\mathrm{pH} 7.5,50 \mathrm{mM}$ $\mathrm{CaCl}_{2}$ ) and PTC solution (6\% polyethylene glycol 3350, $10 \mathrm{mM}$ Tris$\mathrm{Cl}, \mathrm{pH}$ 7.5, $50 \mathrm{mM} \mathrm{CaCl}_{2}$ ).

\section{Protoplast preparation}

G. reesii isolate $\mathrm{Za}-130$ cultured for 3-5 days on PDA medium in a Petri dish was rinsed with 2-3 $\mathrm{mL}$ sterile water, and then the mycelium was transferred to $500 \mathrm{~mL}$ flasks containing $150 \mathrm{~mL} \mathrm{CM}$ liquid medium by $1 \mathrm{~mL}$ tips. The mycelium was cultured at $28^{\circ} \mathrm{C}$ at $130 \mathrm{r} / \mathrm{min}$. After 36, 42 and $48 \mathrm{~h}$, the mycelium was collected with sterile 3 layer lens cleaning paper (Double loop Company, China) with quartet built filter funnel, and then the collected mycelium was fully washed with an osmotic stabilizer. Every 0.3-0.5 g mycelium was transferred to a $50 \mathrm{~mL}$ centrifuge tube. The Driselase (20 $\mathrm{mg} / \mathrm{mL}$, dissolved in $0.7 \mathrm{M} \mathrm{NaCl}$ ) was added in the tube at a ratio of $1.5 \mathrm{~mL}$ enzyme solution per $1 \mathrm{~g}$ mycelium. The mycelium was lysed at $28^{\circ} \mathrm{C}, 120 \mathrm{r} / \mathrm{min}$ for 3 to $6 \mathrm{~h}$. The protoplasts were collected with 3 layer lens cleaning paper, followed by centrifugation $(4000 \mathrm{r} / \mathrm{min}$, $4^{\circ} \mathrm{C}, 15 \mathrm{~min}$ ), and then the protoplasts were resuspended with $1 \mathrm{~mL}$ STC. The number of protoplasts was calculated with a Blood Count Board (Shanghai Refinement Biochemical Instruments Co., LTD, China), and the number of protoplasts collected from $1 \mathrm{~g}$ mycelium lysed by Driselase was defined as the yield of protoplasts.

\section{Protoplast regeneration}

The protoplasts were centrifuged at $4^{\circ} \mathrm{C}$ and $2000 \mathrm{~g}$ for $15 \mathrm{~min}$ and then adjusted to $1 \times 10^{4}$ protoplasts $/ \mathrm{mL}$ with osmotic stabilizer. Protoplasts $(0.1 \mathrm{~mL})$ were spread on the SR or PDA medium plates. Meanwhile, $0.1 \mathrm{~mL}$ protoplasts mixed with $1 \mathrm{~mL}$ sterile water were kept for 30 min under room temperature and then were spread on the SR or PDA plates as controls. The plates were placed at $28^{\circ} \mathrm{C}$ for 3 to 5 days until small colonies emerged on the flat surface. The experiment was conducted for 3 times. The rate of protoplast regeneration $(\%)=[($ number of small colonies on regeneration medium - number of small colonies of CK) / number of protoplasts] $\times 100 \%$.

\section{Transformation mediated by PEG}

The protoplasts were washed three times with $10 \mathrm{~mL} \mathrm{STC} \mathrm{solution}$ and then suspended to a final concentration of $1 \times 10^{8}$ protoplasts $/ \mathrm{mL}$ with STC solution. Transformation was performed by incubating $150 \mu \mathrm{L}$ protoplasts with 2-3 $\mu \mathrm{g}$ linear pKNTG plasmid DNA in a $50 \mathrm{~mL}$ centrifugation tube for $20 \mathrm{~min}$ on ice, and then $2 \mathrm{~mL}$ PTC solution was added. The tube was placed on ice for $20 \mathrm{~min}$, and then $25 \mathrm{~mL}$ STC solution was added and the sample was centrifuged at $4^{\circ} \mathrm{C}$, and $4000 \mathrm{r} / \mathrm{min}$ for $15 \mathrm{~min}$. The pellet was resuspended with $3 \mathrm{~mL} \mathrm{LR}$, and then the mixture was put into the incubator at $28^{\circ} \mathrm{C}$ for $12 \mathrm{~h}$. The mixture was added to SR to pour on plates and then covered with $0.7 \%$ top agar that contained 400 $\mu \mathrm{g} / \mathrm{mL}$ of neomycin. The plates were placed in the RXZ illuminating incubator (Ningbo Jiangnan Instrument Company, China) until small colonies were observed, with 12 hours of light cycle at $28^{\circ} \mathrm{C}$.

\section{DNA extraction}

Genomic DNA was extracted from mycelia using the hexadecyl trimethyl ammonium bromide (CTAB) procedure described by Talbot et al. (1993). Plasmid DNA was isolated by the method of Noguchi (1991).

\section{Identification of transformants}

The GFP gene was amplified from the DNA extracted from transformants with GFP-F/R primers (GFP-F: 5ATGGTGAGCAAGGGCGAGG-3, GFP-R: 5TTACTTGTACAGCTCGTCC-3). The polymerase chain reaction (PCR) mixture $(25 \mu \mathrm{L})$ was as follows: $0.25 \mu \mathrm{L}$ of rTaq DNA polymerase $(5 \mathrm{U} / \mathrm{L}), 2.5 \mu \mathrm{L}$ of $10 \times$ buffer (plus $\mathrm{Mg}^{2+}$ ), $1 \mu \mathrm{L}$ of extracted genomic DNA, $0.5 \mu \mathrm{L}$ of GFP-F primer $(10 \mu \mathrm{mol} / \mathrm{L}), 0.5 \mu \mathrm{L}$ of GFP-R primer (10 $\mu \mathrm{mol} / \mathrm{L}), 2 \mu \mathrm{L}$ of dNTP (each $2.5 \mathrm{mmol} / \mathrm{L}$ ) and 


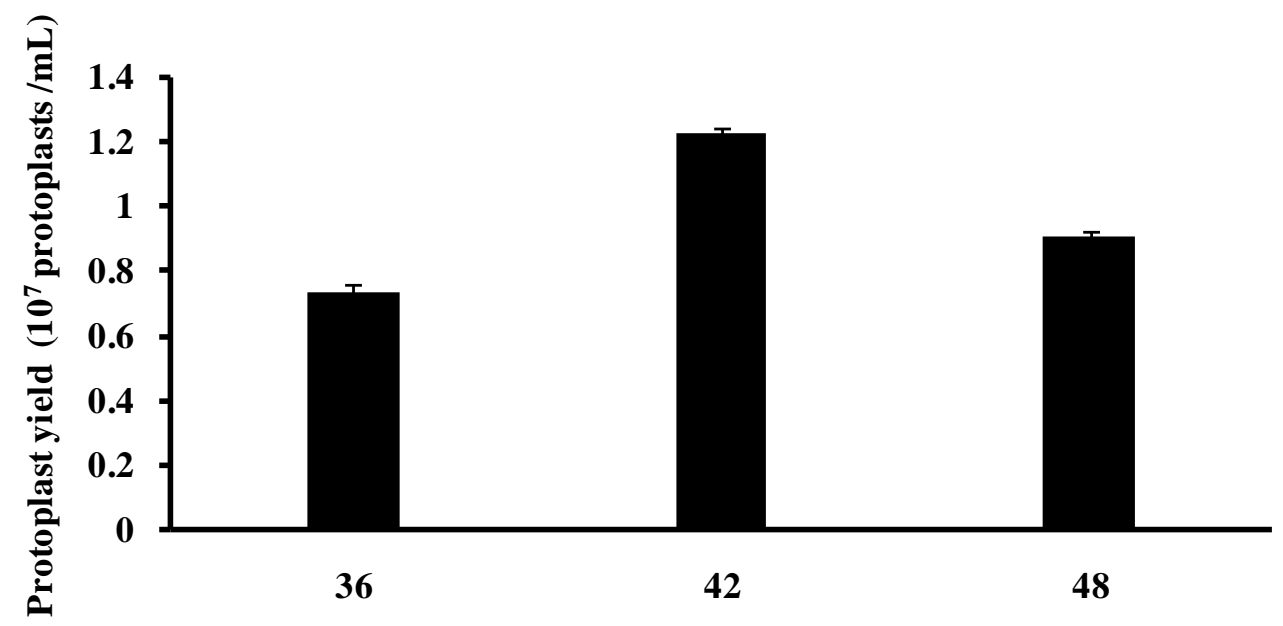

Culture time (h)

Figure 1. Effect of culture times on the protoplast yield.

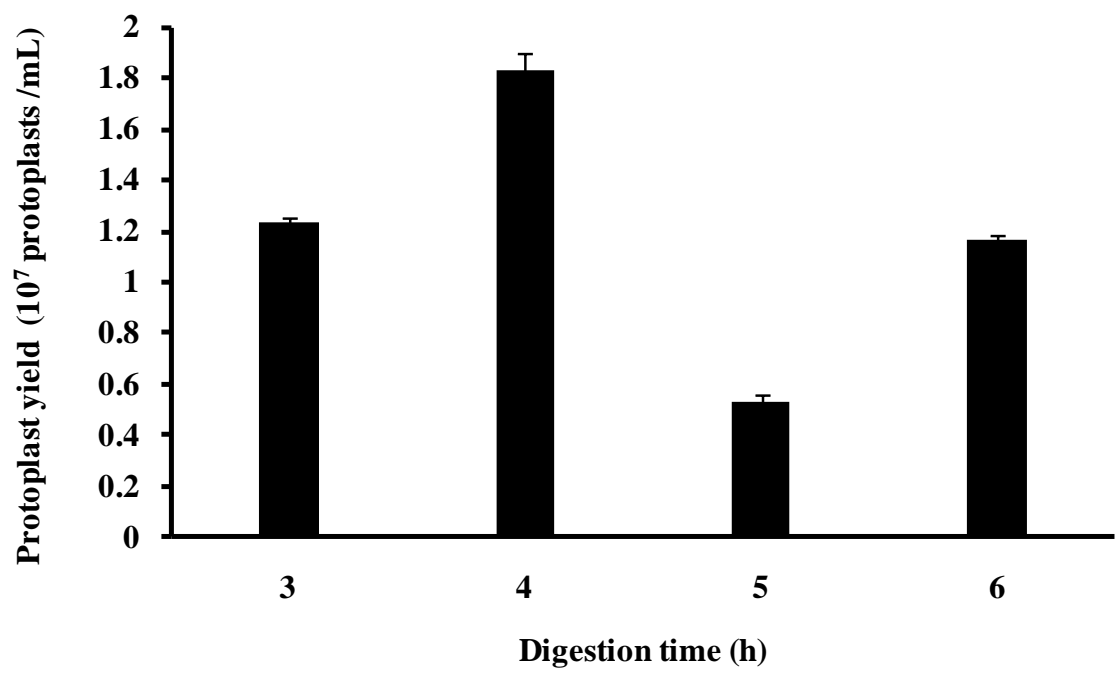

Figure 2. Effect of digestion time on the protoplast yield

18.25 $\mu \mathrm{L}$ of deionized water. The $\mathrm{PCR}$ reaction conditions were as follows: 30 cycles of $95^{\circ} \mathrm{C}$ for $1 \mathrm{~min} ; 56^{\circ} \mathrm{C}$ for $1 \mathrm{~min} ; 2^{\circ} \mathrm{C}$ for $1 \mathrm{~min}$, with a start of $95^{\circ} \mathrm{C}$ for $4 \mathrm{~min}$ and finish of $72^{\circ} \mathrm{C}$ for $10 \mathrm{~min}$. PCR products were detected by $1.0 \%$ agarose gel electrophoresis.

Fluorescent hyphae were identified using a Nikon ECLIPSE 80i (Nikon, Japan) with UV light. The GFP signal was observed with a Nikon DS-Ri1 (Nikon, Japan), and images were analyzed by NISElement D (Nikon, Japan).

\section{RESULTS}

\section{The optimal mycelium culture time}

The mycelium was cultured for 36,42 , or $48 \mathrm{~h}$ and lysed. When the mycelium was cultured in medium for $42 \mathrm{~h}$, the yield of protoplasts reached a peak of $1.24 \times 10^{7}$ protoplasts $/ \mathrm{mL}$ (Figure 1). These results suggest that the lysis of mycelium may correlate with the growth of the cell wall and that when the mycelium was cultured for $42 \mathrm{~h}$, the conditions of the cell wall were suitable for lysis.

\section{The optimal mycelium cell wall digestion time}

The yield of protoplasts was compared after different digestion periods with Driselase, from 2 to $6 \mathrm{~h}$. The results (Figure 2) indicated that the yield was highest at 4 $h$ digestion. However, the difference between the yields at 3 and $6 \mathrm{~h}$ was not significant. 


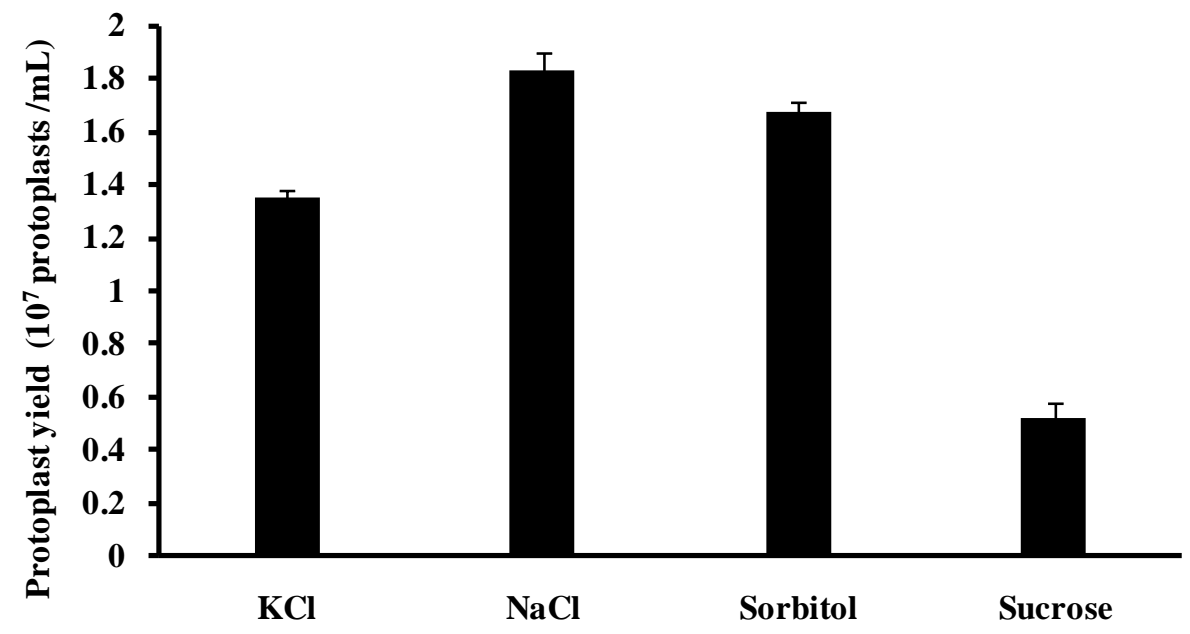

Osmotic stabilizer

Figure 3. Effect of the osmotic stabilizer on the protoplast yield.

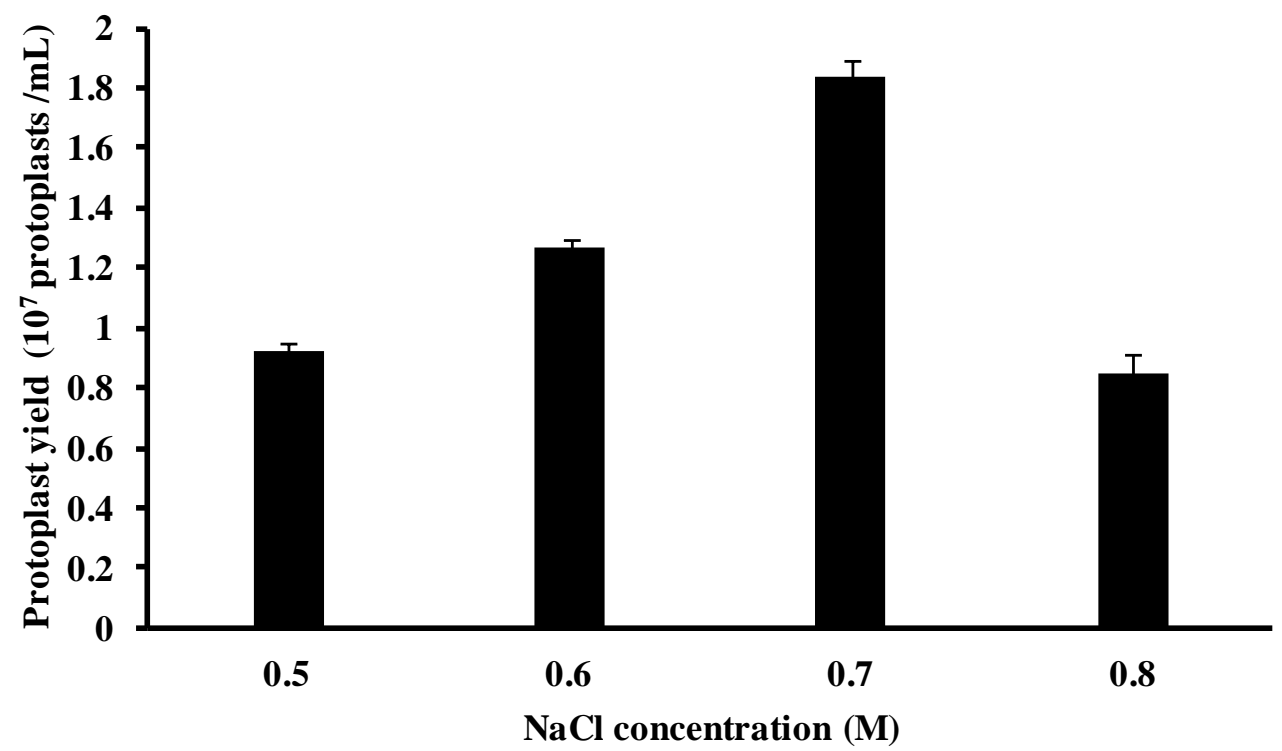

Figure 4. Effect of $\mathrm{NaCl}$ concentrations on the protoplast yield.

The optimal osmotic stabilizer for protoplast preparation

$\mathrm{KCl}, \mathrm{NaCl}$, sorbitol and sucrose solution were candidate osmotic stabilizers tested in this study (all solution concentrations were $0.7 \mathrm{M}$ ). The results (Figure 3) indicated that $\mathrm{NaCl}$ is the most suitable osmotic stabilizer for protoplast release from $G$. reesii. Different concentrations were tested to determine the optimal concentration, and the results shown in Figure 4 demonstrate that $0.7 \mathrm{M} \mathrm{NaCl}$ was the best osmotic stabilizer.

The optimal regeneration medium for protoplast regeneration

PDA and SR medium were tested as candidate medium for regeneration. With a digestion time of $4 \mathrm{~h}$, the regeneration rates of protoplasts on PDA and SR reached peaks of 19.21 and $21.17 \%$ (Figure 5), respectively. The differences between the two mediums were minor, but the 


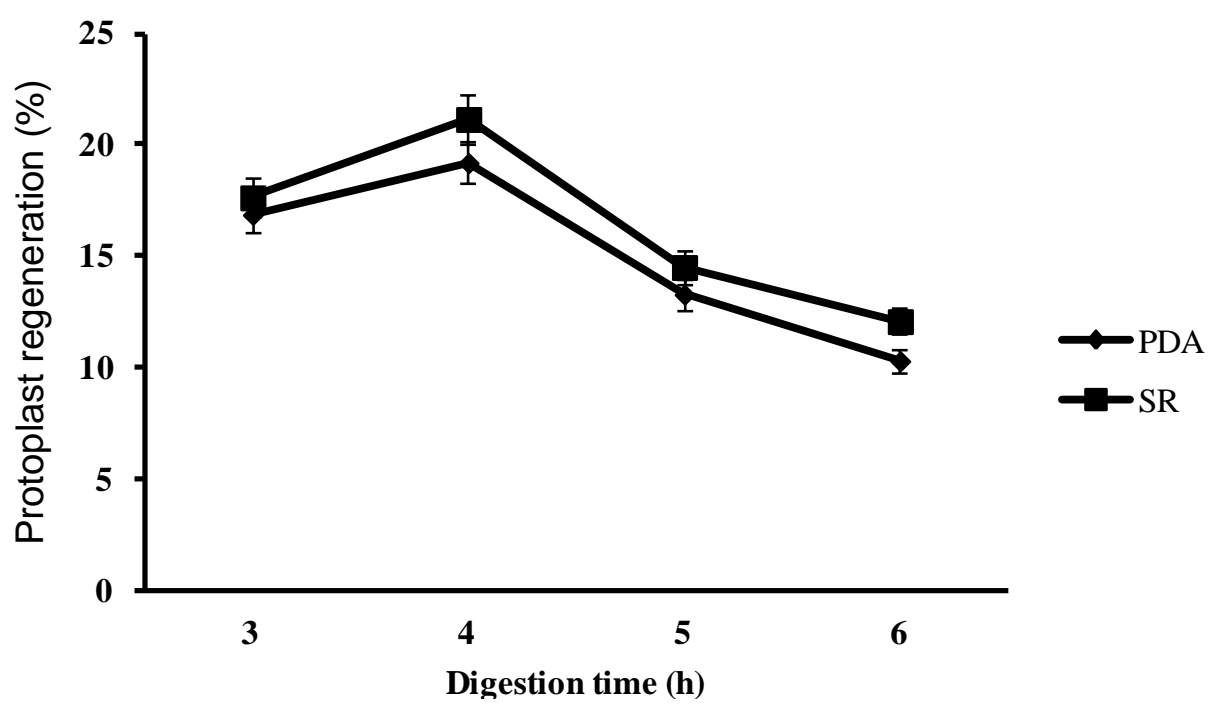

Figure 5. Effect of the medium and digestion time on the regeneration of protoplasts.

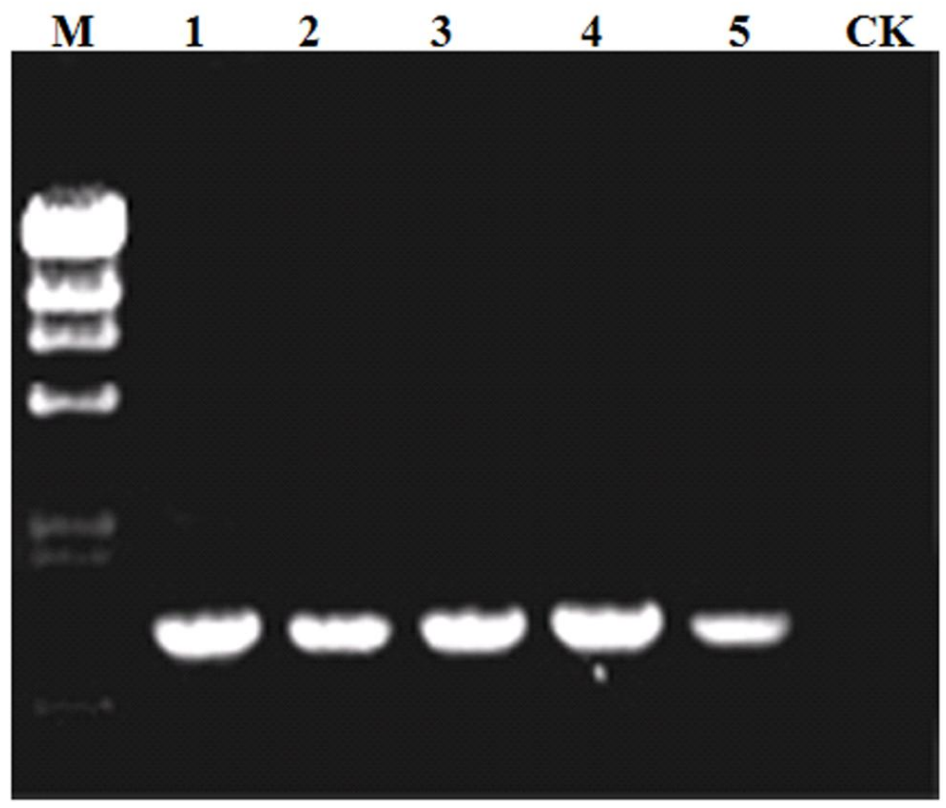

Figure 6. Confirmation of the integration of the plasmid pKNTG into transformant genomic DNA by PCR analysis with GFP-specific primers. M, $\lambda$ DNA digested by Hindlli; 1-5, five transformants randomly chosen; $\mathrm{CK}, \mathrm{Za}-130$ was used as a negative control.

SR medium was more suitable for these experimental conditions.

\section{Identification of transformants by PCR and fluorescent microscopy}

20 transformants of $G$. reesii were obtained by transforming the linear pKNTG into wild type G. reesii. Ectopic integration of the construct was demonstrated by PCR amplification and GFP fluorescence. The 720 base pair nucleotide sequence of the GFP gene was amplified in all 20 resulting transformants as shown in Figure 6. The GFP from random positive transformants was detected in mycelia, whereas the control mycelia without transformation displayed no GFP (Figure 7). 

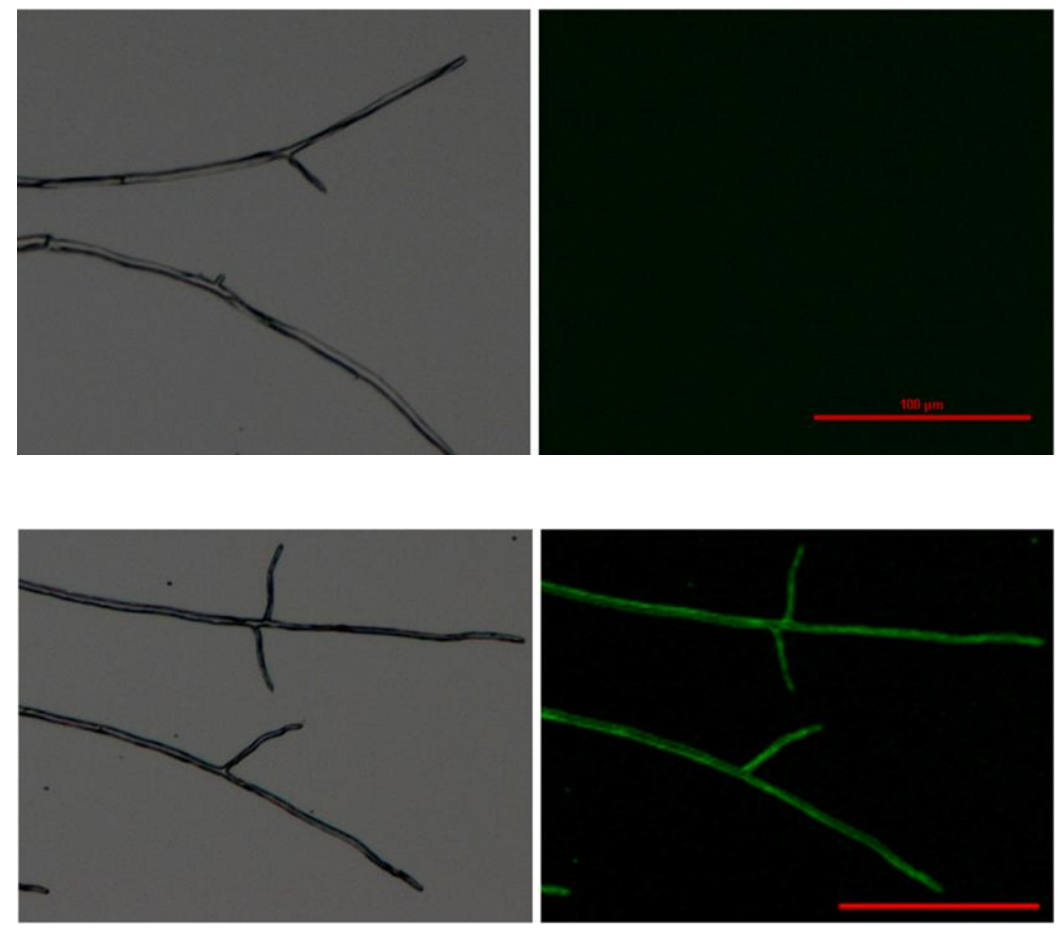

Figure 7. Expression of green fluorescent protein in G. reesii Hyphae of nontransformed Za-130 imaged under white light $(A)$ and UV light (B). Hyphae of a transformant observed under white light (C) and UV light (D).

\section{DISCUSSION}

Plant disease caused by nematodes is a serious problem in the world, and fungal natural products are very promising potential sources of new chemicals to manage this (Anke and Sterner, 1997). Some biocontrol materialcontaining fungus commonly produce active compounds at low levels, and modification by molecular manipulation for efficient production of natural compounds or metabolic products is necessary. Protoplast preparation and regeneration is a key technology in molecular fungal research. PEG is a chemical that can alter the membrane of the fungal cell and allow exogenous DNA to enter into the cell. In the study, we used PEG and observed a high transformation efficiency. For the preparation of protoplasts, the type of culture medium, time of culture, and cell wall-degrading enzyme are the most important factors. The osmotic stabilizer not only affects protoplast release from the mycelium but also the activity of the enzyme, so a suitable osmotic stabilizer is also very important. The concentration of the osmotic stabilizer is another important factor that can affect protoplast release from $G$. reesii. When the concentration is high, the protoplast release will be inhibited, while low concentrations will cause protoplasts to expand and perhaps even burst. The digestion time and the type of regeneration medium can also affect the regeneration rate of protoplasts. In the study, we optimized each of these factors with a series of experiments. The transformation system is stable and convenient, and we can get enough protoplast every time in our study.

Many functional genes have been isolated by insertional mutagenesis in the past few decades in different fungi (Sweigard et al., 1998; Bölker et al., 1995; Kang et al., 1994; Kuspa and Loomis 1992; Balhadere et al., 1999). We also simplified the Restriction Enzyme Mediated Integration (REMI) procedure so that daily transformation can be conveniently performed (results unpublished). At the same time, we also constructed the REMI transformation system, and got more than 2000 REMI transformants for gene functional analysis in future (data not shown).

The results reported in this paper have encouraged us to proceed with efforts to clone G. reesii functional genes that control or affect the production of compounds with bioactivity toward nematodes by transforming appropriate G. reesii recipients with suitable vectors. We have also constructed a library that contains 2016 REMI transformants that will be screened for isolates with more or less efficient production of nematicidal compounds.

\section{ACKNOWLEDGEMENTS}

This work was partially supported by CARS-30, the National Science Foundation of China (30900940) and 
the Natural Science Foundation of Beijing (610200).

\section{REFERENCES}

Anke H, Sterner O (1997). Nematicidal metabolites from higher fungi. Curr. Org. Chem. 1:361-374.

Balhadere PV, Foster AJ, Talbot NJ (1999). Identification of pathogenicity mutants of the rice blast fungus Magnaporthe grisea by insertional mutagenesis. Mol. Plant Microbe Interact. 12:129-142.

Benjamin RC, Robert JC, Ernest L, Shaun T, Jennifer HG, Benjamin B, Gerhard B (2005). Gymnoascolides A-C: romatic Butenolides from an Australian isolate of the soil ascomycete Gymnoascus reesii. J. Nat. Prod. 68(8):1226-1230.

Benjamin RC, Robert JC, Ernest L, Shaun T, Jennifer HG (2006). Polyenylpyrroles and polyenylfurans from an Australian isolate of the soil ascomycete Gymnoascus reessii. Org. Lett. 8(4):701-704.

Bölker M, Böhnert HU, Braun KH, Görl J, Kahmann R (1995). Tagging pathogenicity genes in Ustilago maydis by restriction enzymemediated integration (REMI). Mol. Gen. Genet. 248:547-552.

Case ME, Schweizer M, Kushner SR, Giles NH (1979). Efficient transformation of Neurospora crassa by utilizing hybrid plasmid DNA. Proc. Natl. Acad. Sci. USA 76(10):5259-5263.

Colot HV, Park G, Turner GE, Ringelberg C, Crew CM, Litvinkova L, Weiss R, Borkovich KA, Dunlap JC (2006). A high-throughput gene knockout procedure for Neurospora reveals functions for multiple transcription factors. Proc. Natl. Acad. Sci. USA 103(27):1035210357.

Hamer L, Adachi K, Montenegro-Charmorro MV, Tanzer MM, Mahanty SK, Lo C, Tarpey RW, Skalchunes AR, Heiniger RW, Frank SA, Darveaux BA, Lampe DJ, Slater TM, Ramamurthy L, Dezwaan TM, Nelson GH, Shuster JR, Woessner J, Hamer JE (2001). Gene discovery and gene function assignment in filamentous fungi. Proc. Natl. Acad. Sci. USA 98(9):5110-5115.

Hinnen A, Hicks JB, Fink GR (1978). Transformation of Yeast. Proc. Natl. Acad. Sci. USA, 75:1929-1933.

Kang S, Chumley FG, Valent B (1994). Isolation of the mating type genes of the phytopathogenic fungus Magnaporthe grisea using genomic subtraction. Genetics 138:289-296.

Kuspa A, Loomis WF (1992). Tagging developmental genes in Dictyostelium by restriction enzyme-mediated integration of plasmid DNA. Proc. Natl. Acad. Sci. USA 89:8803-8807.

Liu JH, Wang L, Qiu JY, Jiang LL, Yan JY, Liu T, Liu WC, Duan YX (2011). Nematicidal activity of Gymnoascus reesii against Meloidogyne incognita. Afr. J. Microbiol. Res. 5(18):2715-2719.

Liu T, Duan YX, Chen LJ (2004). Studies on the selective toxin of fungus metabolites to nematode. The XVth international plant protection congress, Beijing, China. Foreign Languages Press. p. 420.
Manczinger L, Komonyi O, Antal Z, Ferenczy L (1997). A method for high-frequency transformation of Trichoderma viride. J. Microbiol. 29:207-210.

Montero-Barrientos M, Hermosa R, Cardoza RE, Gutierrez S, Monte E (2011). Functional analysis of the Trichoderma harzianum nox1 gene, encoding an NADPH oxidase, relates production of reactive oxygen species to specific biocontrol activity against Pythium ultimum. Appl. Environ. Microbiol. 77(9):3009-3016.

Noguchi T (1991). Mini-Maxi prep: An efficient and inexpensive procedure for medium scale preparation of high quality supercoiled plasmid DNA. Technique 3:33-36.

Parsons KA, Chumley FG, Valent B (1987). Genetic transformation of the fungal pathogen responsible for rice blast disease. Proc. Natl. Acad. Sci. 84:4161-4165.

Penttila M, Nevalainen H, Ratto M, Salminen E, Knowles J (1987). A versatile transformation system for the cellulolytic filamentous fungus Trichoderma reesei. Gene 61:155-164.

Pozo MJ, Baek JM, Garcia JM, Kenerley CM (2004). Functional analysis of $t v s p 1$, a serine protease-encoding gene in the biocontrol agent Trichoderma virens. Fungal Genet. Biol. 41(3):336-348.

Schiestl RH, Petes TD (1991). Integration of DNA fragments by illegitimate recombination in Saccharomyces cerevisiae. Proc. Natl. Acad. Sci. USA 88(17):7585-7589.

Sweigard JA, Carroll AM, Farrall L, Chumley FG, Valent B (1998). Magnaporthe grisea pathogenicity genes obtained through insertional mutagenesis. Mol. Plant Microbe Interact. 11(5):404-412.

Talbot NJ, Ebbole DJ, Hamer JE (1993). Identification and characterization of MPG1, a gene involved in pathogenicity from the rice blast fungus Magnaporthe grisea. Plant Cell 5:1575-1590.

Wang B, Liu LX, Gao YD, Chen J (2009). Improved phytoremediation of oilseed rape (Brassica napus) by Trichoderma mutant constructed by restriction enzyme-mediated integration (REMI) in cadmium polluted soil. Chemosphere 74(10):1400-1403.

Yang Q, Cong H, Zhang HY, Yao L, Liu PG, Jin HX (2007). Study on biocontrol related genes of Trichoderma sp. and Chaetomium spp. KMITL Sci, Tech. J. 7(1):8-15.

Yelton MM, Hamer JE, Timberlake WE (1984). Transformation of Aspergillus nidulans by using a trpC plasmid. Proc. Natl. Acad. Sci. USA 81(5):1470-1474. 